\title{
Penerapan Model Learning Cycle Untuk Meningkatkan Hasil Belajar Kognitif dan Keterampilan Proses Sains Pada Materi Usaha dan Energi di Kelas X MIA 3 MAN 2 Kota Bengkulu.
}

\author{
Anggi Dwi Saputri, Rosane Medriati, Nyoman Rohadi \\ Prodi S1 Pendidikan Fisika FKIP-UNIB \\ Email : Anggiedwisaputrie@gmail.com
}

\begin{abstract}
ABSTRAK
Penelitian ini merupakan penelitian tindakan kelas yang bertujuan untuk meningkatkan aktivitas, hasil belajar kognitif siswa dan keterampilan proses sains siswa pada materi usaha dan energi yang dilakukan dalam empat tahap yaitu perencanaan, tindakan, pengamatan dan refleksi. Subjek dalam penelitian ini adalah seluruh siswa kelas X MIA 3 yang berjumlah 39 siswa. instumen yang digunakan adalah lembar observasi aktivitas guru dan siswa, tes hasil kognitif dan tes keterampilan proses sains. Hasil penelitian diperoleh bahwa aktivitas belajar siswa pada siklus I dengan rata-rata skor 23 (kategori cukup), meningkat pada siklus II menjadi 25 (kategori baik) dan meningkat lagi pada siklus III menjadi 28 (kategori baik). Hasil belajar kognitif siswa untuk siklus I diperoleh nilai rata-rata 70,25, meningkat pada siklus II menjadi 76,41 dan meningkat lagi pada siklus III menjadi 84,61. Keterampilan proses sains siswa meningkat dari siklus I hingga siklus III terutama keterampilan proses sains pada aspek mengajukan pertanyaan dengan skor rata-rata sebesar 82,04. Berdasarkan hasil penelitian dapat disimpulkan bahwa penerapan Learning Cycle 5E dapat meningkatkan aktivitas belajar, hasil belajar kognitif dan keterampilan proses sains siswa.

Kata kunci : Learning Cycle, aktivitas belajar, hasil belajar kognitif, keterampilan proses sains
\end{abstract}

\begin{abstract}
This research is a classroom action research was aimed to determine the increase of learning activities, cognitive learning outcomes science process skills of students. Subjects in this research were all students of class X MIA 3 which amounted to 39 students. This research was conducted in four steps: planning, acting, observing, and reflecting. The results of this research indicate that student learning activity in cycle I with average score of 23 (enough category), increased in cycle II to 25 (good category) and increased returns to cycle III to 28 (good category). The students' cognitive learning outcomes for the cycle I obtained an average of 70,25, increased in cycle II to 76,41 and increased again in the cycle III to 84,61. The students science process skills from cycle I until cycle III especially science proses skill to aspect of question with average score equal to 82,04. Based on the results of research can be concluded that the application of Learning Cycle model can increase the learning activities, learning outcomes and science process skills of students.
\end{abstract}

Keywords: Learning Cycle, learning activities, cognitive learning outcomes, science process skills

\section{PENDAHULUAN}

Pembelajaran Sains adalah suatu konsep dari dua dimensi aktivitas belajar mengajar yang harus direncanakan dan diaktualisasi kan, serta diarahkan pada pencapaian tujuan dan penguasaan sejumlah kompetensi dan indikatornya sebagai hasil belajar [1]. Proses pembelajaran IPA lebih ditekankan pada pendekatan keterampilan proses agar siswa dapat menemukan faktafakta, membangun konsep-konsep, teori-teori dan sikap ilmiah siswa itu sendiri yang memberikan dampak positif pada terhadap kualitas proses pendidikan maupun produk 
pendidikan. Secara umum IPA (sains) meliputi tiga bidang ilmu dasar, yaitu biologi, fisika dan kimia [2].

Keterampilan proses sains adalah seluruh keterampilan ilmiah yang digunakan untuk menemukan konsep atau prinsip atau teori dalam rangka mengembangkan konsep yang telah ada atau menyangkal penemuan sebelumnya. Keterampilan proses ini diperlukan untuk memperoleh, mengembangkan dan menerapkan konsep-konsep, prinsip hukum dan teori-teori sains [3].

Proses pembelajaran dapat dipadukan dengan suatu proses ilmiah, karena itu Kurikulum 2013 mengamanatkan esensi pendekatan saintifik dalam pembelajaran. pendekatan saintifik dalam kurikulum 2013 juga sangat relevan dengan tiga teori belajar, yaitu teori Bruner, teori Piaget, dan teori Vygotsky. Pada setiap langkah inti proses pembelajaran, pendidik akan melakukan langkah-langkah pembelajaran sesuai dengan model pembelajaran konstruktivistik. Terdapat beberapa model yang dilandasi konstruktivistik yaitu model siklus belajar (Learning Cycle), model pembelajaran generative, model pembelajaran interaktif, model CLIS (Children Learning in Science) dan model strategi pembelajaran kooperatif.

Pembelajaran siklus (learning Cycle) merupakan salah satu model pembelajaran dengan pendekatan konstruktivis yang pada mulanya terdiri atas tiga tahap, yaitu: eksplorasi (exploration), pengenalan konsep (concept introduction) dan penerapan konsep (concept application). Pada proses selanjutnya, tiga tahap siklus tersebut mengalami pengembangan. Tiga siklus tersebut saat ini dikembangkan menjadi lima tahap oleh Lorsbach yang terdiri atas tahap pembangkitan minat (engagement), eksplorasi (exploration), penjelasan (eksplanation), elaborasi (elaboration) dan evaluasi (evaluation) [4].

Hasil observasi di kelas X MIA 3 MAN Kota Bengkulu bahwa: (1) Metode yang biasa digunakan guru dalam mengajar adalah ceramah. Sehingga menyebabkan siswa menjadi pasif (duduk,dengar dan catat). (2) Proses pembelajaran dikelas masih berpusat pada guru (teacher centered) yang mengakibatkan siswa hanya mendapatkan materi yang hanya disampaikan oleh guru tanpa melibatkan siswa langsung dalam pembelajaran. (3) Sistem evaluasi pembelajaranpun hanya berfokus pada aspek kognitif tanpa memperhatikan aspek keterampilan proses sains yang harus dimiliki siswa. Masalah lain dari segi siswa kelas X MIA 3 MAN 2 Kota Bengkulu bahwa : (1) Siswa masih menganggap bahwa fisika itu sulit dipahami dan membosankan. (2) Hasil belajar aspek pengetahuan dari 33 siswa hanya $27 \%$ siswa yang telah melampaui KKM yang sebesar 75 . (3) Siswa hanya dilibatkan 2 kali dalam kegiatan eksperimen dan bekerja sama dengan siswa lain sehingga siswa kurang terampil dalam mengamati, berkomunikasi, memprediksi, mengukur, mengklasifikasikan dan menyimpulkan pembelajaran. (4) Siswa belum pernah mengikuti kompetisi seperti olimpiade sains dan matematika, kompetisi robotik dan kompetisi bidang saintek lainnya, selain kompeten dibidang ilmu keagamaan. Padahal seharusnya siswa juga harus dapat menguasai kompetensi pendidikan sains, yaitu penguasaan produk sains, proses sains, dan sikap ilmiah. Ketiga aspek tersebut dimotori oleh keterampilan proses sains.

Berdasarkan uraian diatas, maka perlu dilakukan adanya inovasi dalam proses pembelajaran yang dapat memperbaiki permasalahan tersebut. Salah satu solusi yang dapat diterapkan adalah menggunakan penerapan model Learning Cycle 5E. Model pembelajaran ini sesuai untuk meningkatkan aktivitas siswa, hasil belajar kognitif dan keterampilan proses sainsnya, hal ini dikarenakan siswa mengkonstruksi sendiri pengetahuannya melalui sebuah kegiatan eksplorasi bersama kelompoknya dan menerapkan konsep-konsep yang ditemukannya pada permasalahan yang baru serta terlibat langsung secara aktif dalam proses pembelajaran.

Oleh karena itu, dalam upaya mencapai ke arah tujuan penelitian ini, yaitu untuk meningkatkan aktivitas, hasil belajar kognitif dan keterampilan proses sains siswa dalam pembelajaran fisika, maka penulis melakukan penelitian tindakan kelas dengan judul penelitian "Penerapan Model Learning Cycle Untuk Meningkatkan Hasil Belajar Kognitif dan 
Keterampilan Proses Sains Pada Materi Usaha dan Energi di Kelas X MIA 3 MAN 2 Kota Bengkulu".

\section{METODOLOGI PENELITIAN}

Penelitian ini merupakan penelitian tindakan kelas (Classroom Action Research). Tahapan dalam PTK meliputi perencanaan, tindakan, pengamatan dan refleksi. Penelitian ini telah dilaksanakan pada bulan April 2018 di MAN 2 Kota Bengkulu tahun ajaran 2017/2018. Subyek yang diteliti adalah siswa-siswi kelas X MIA 3 MAN 2 Kota Bengkulu sebanyak 39 siswa. Seiap siklus penelitian tindakan kelas terdiri atas empat tahap, yaitu (1) Perencanaan, (2) Tindakan, (3) Observasi, dan (4) Refleksi.

Instrumen yang digunakan dalam penelitian ini adalah lembar observasi, tes hasil belajar dan tes keterampilan proses sains. Data yang diperoleh adalah aktivitas guru dan aktivitas belajar siswa, hasil belajar kognitif dan keterampilan proses sains pada setiap siklus. Lembar observasi aktivitas guru dan aktivitas belajar siswa terdiri dari lima langkah Learning Cycle 5E dengan 10 aspek yang diamati. Penilaian aktivitas guru dan aktivitas belajar siswa oleh dua orang pengamat berdasarkan rubrik penilaian aktivitas guru dan belajar siswa.

Analisis untuk aktivitas guru dan aktivitas belajar siswa dilihat dari skor yang diperoleh berdasarkan pengamatan oleh dua orang observer, yaitu guru fisika MAN 2 Kota Bengkulu dan satu orang mahasiswa pendidikan fisika Universitas Bengkulu. Pembelajaran dikatakan berhasil jika skor rata-rata aktivitas guru dan aktivitas belajar siswa dalam kategori baik.

Menghitung skor rata-rata menggunakan rumus:

$$
X=\frac{\Sigma\left(P_{1}+P_{2}\right)}{2}
$$

Hasil belajar kognitif diukur melalui lima buah soal pilihan ganda. Tingkat kesukaran soal bervariasi, yaitu mulai dari C1 (pengetahuan), C2 (pemahaman) dan C3 (aplikasi). Analisis untuk hasil belajar kognitif siswa dilihat dari peningkatan ketuntasan belajar klasikal pada setiap siklusnya. Pembelajaran dikatakan berhasil jika skor rata-rata hasil belajar siswa $=75$ atau ketunntasan belajar klasikal telah mencapai $80 \%$. Skor rata-rata hasil belajar siswa dihitung dengan menggunakan rumus:

$$
\bar{X}=\frac{\sum x_{i}}{n}
$$

Menghitung ketuntasan belajar klasikal $(\mathrm{KB})$ menggunakan rumus:

$$
K B=\frac{N_{S}}{N} \times 100 \%
$$

Keterampilan proses sains (KPS) diukur melalui soal essai yang berjumlah lima butir. Setiap butir soal mengukur satu indikator KPS. Indikator KPS yang diukur dalam penelitian ini adalah keterampilan mengamati, mengajukan pertanyaan, merumuskan hipotesis,, menerapkan konsep dan berkomunikasi. [5] Analisis data keterampilan proses sains dilihat dari peningkatan skor ratarata keterampilan proses sains pada setiap siklus. Predikat capaian kompetensi KPS dapat dilihat pada tabel 2.1.

Tabel 1. Predikat capaian kompetensi KPS

\begin{tabular}{|c|c|}
\hline Rentang nilai & Interpretasi \\
\hline 55 & Kurang \\
\hline $56-70$ & Cukup \\
\hline $71-85$ & Baik \\
\hline $86-100$ & Sangat baik \\
\hline
\end{tabular}




\section{HASIL DAN PEMBAHASAN \\ 3.1 Aktivitas Belajar Siswa}

Berdasarkan hasil penelitian pada proses pembelajaran dengan menggunakan model Learning Cycle 5E dari empat siklus yang telah dilaksanakan terjadi peningkatan aktivitas belajar siswa seperti pada gambar 3.1.

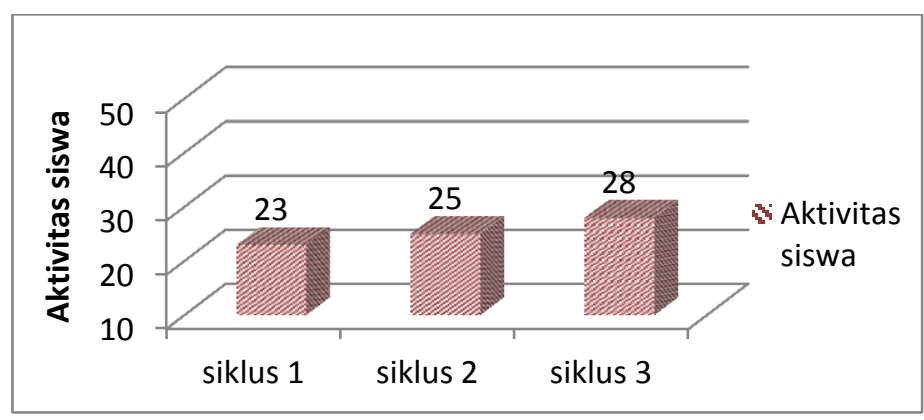

Gambar 1. Grafik Skor Perkembangan Aktivitas Belajar Siswa

Berdasarkan gambar 1 terlihat bahwa rata-rata aktivitas siswa dari ketiga siklus mengalami peningkatan. Pada siklus I terlihat skor rata-rata dari dua pengamat yaitu 23 dengan kategori cukup. Kemudian pada siklus II meningkat dengan skor rata-rata yang diperoleh yaitu 25 dengan kategori baik. Siklus III meningkat lagi yaitu skor rata-rata yang diperoleh adalah dengan kategori baik.

Peningkatan aktivitas belajar siswa dalam pembelajaran dengan menerapkan model DL ini terjadi karena pada setiap siklusnya direfleksi untuk perbaikan dan direncanakan ulang agar proses pembelajaran pada siklus berikutnya menjadi lebih baik. Sebagaimana yang di kemukakan Tania (2017) dalam penelitiannya bahwa penerapan model Learning Cycle 5E menjadikan pembelajaran berpusat pada siswa dan fase-fase model ini membuat siswa menjadi lebih aktif dalam membangun pengetahuannya sendiri melalui kegiatan nyata atau konkrit [6].

\subsection{Hasil Belajar Kognitif}

Pada empat siklus yang telah dilaksanakan dengan menerapkan model Learning Cycle 5E terjadi peningkatan nilai rata-rata hasil belajar kognitif tiap siklusnya. Nilai rata-rata hasil belajar kognitif dapat dilihat pada gambar 2.

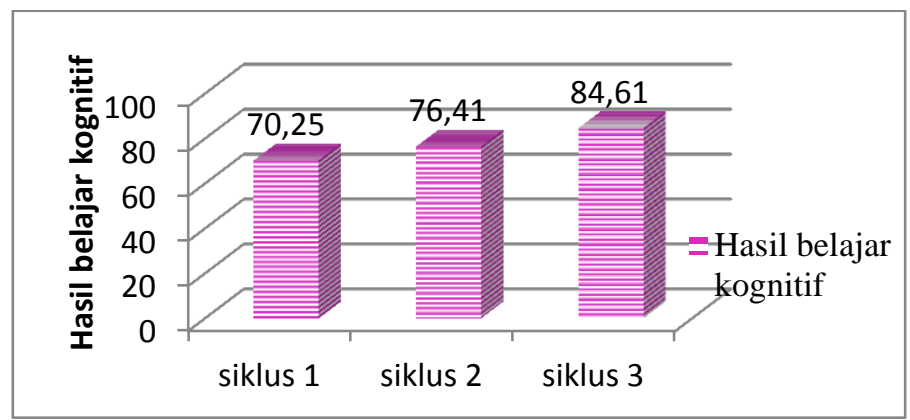

Gambar 2. Grafik Skor Rata-rata Hasil Belajar Kognitif Tiap Siklus

Berdasarkan gambar 2. terlihat bahwa ada peningkatan pada setiap siklusnya. Pada siklus I nilai rata-rata hasil belajar kognitif siswa sebesar 70,25, kemudian meningkat pada siklus II dengan nilai rata-rata 76,41 dan pada siklus III meningkat lagi menjadi 84,61. Hal ini didukung oleh hasil penelitian Yuliani (2014) yang menyimpulkan bahwa penerapan Learning Cycle 5E dapat meningkatkan hasil belajar siswa. Karakteristik kegiatan belajar pada tahap Learning Cycle 
5E mencerminkan pengalaman belajar yang berinteraksi langsung dengan lingkungan dalam mengkonstruksi pengetahuan. Sehingga berhasil meningkatkan hasil belajar kognitif siswa [7].

\subsection{Keterampilan Proses Sains}

Keterampilan Proses Sains (KPS) siswa dinilai melalui hasil tes uraian sebanyak lima butir soal disetiap akhir pembelajaran siswa. Setiap butir soal mewakili satu aspek KPS yang diukur. Aspek KPS yang dinilai dalam penelitian ini yaitu mengamati, mengajukan pertanyaan, merumuskan hipotesis, menerapkan konsep dan berkomunikasi. Adapun nilai rata-rata tes KPS tiap siklusnya dapat dilihat pada tabel gambar 3.

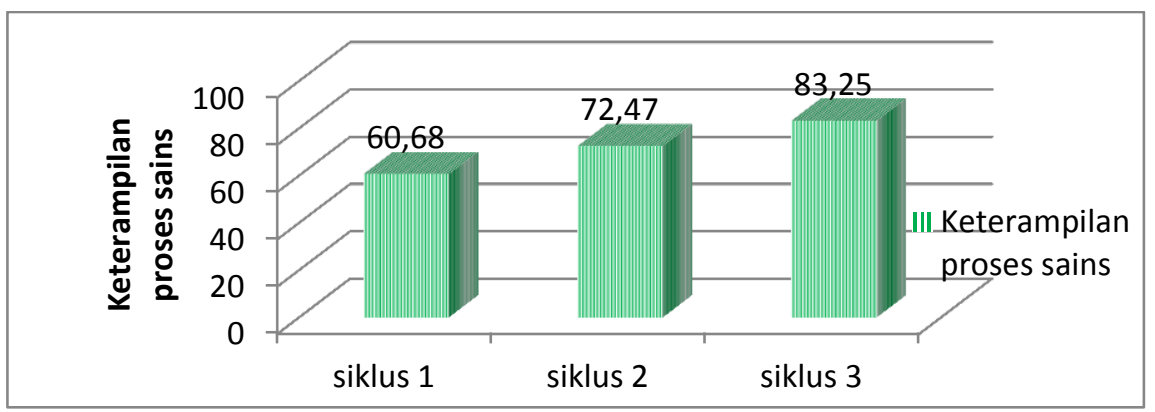

Gambar 3. Grafik Skor Rata-rata Keterampilan Proses Sains Tiap Siklus

Berdasarkan gambar 3. memperlihatkan hasil KPS siswa mengalami peningkatan tiap siklusnya. Peningkatan terjadi karena selalu dilakukan perbaikan dari setiap akhir siklus. Pada siklus I skor rata-rata diperoleh sebesar 60,68 dengan kategori cukup. Pada siklus II skor rata-rata diperoleh sebesar 72,47 dengan kategori baik. Pada siklus III skor rata-rata diperoleh sebesar 83,25 dengan kategori sangat baik. Sesuai dengan hasil penelitian yang dilakukan oleh Tania (2017) bahwa Penerapan model pembelajaran Learning Cycle $5 E$ membuat KPS siswa meningkat terutama pada fase exploration karena siswa melakukan kegiatan eksplorasi dan investigasi. Sehingga siswa dapat melatih keterampilan mengamati, mengomunikasikan, mengelompokkan, mengukur, menginferensi, memprediksi, berhipotesis dan mendefinisikan variabel.

Hasil KPS jika dilihat tiap aspeknya pada setiap dapat dilihat pada gambar 4 di bawah ini.

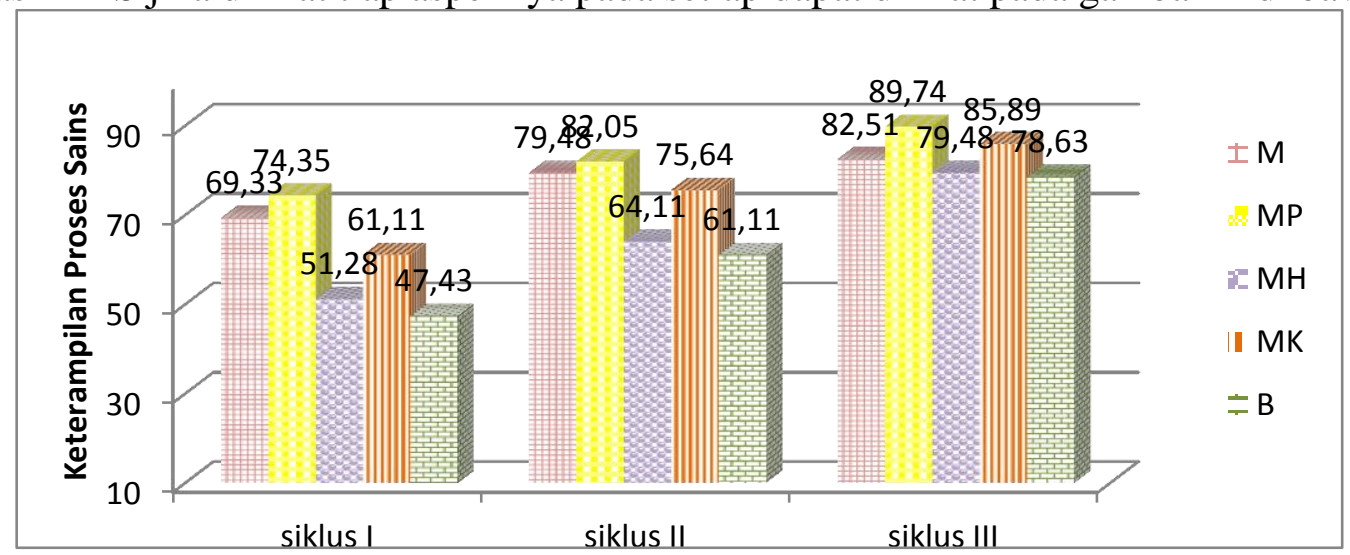

Gambar 4. Grafik Hasil KPS Tiap Siklus

\section{KESIMPULAN DAN SARAN}

\subsection{Kesimpulan}

Berdasarkan hasil penelitian dan pembahasan, diperoleh kesimpulan sebagai berikut: (1) Penerapan model Learning Cycle 5E pada konsep usaha dan energi dapat meningkatkan aktivitas belajar siswa kelas X MIA 3 MAN 2 Kota Bengkulu pada tiap siklusnya. Pada siklus I skor rata- 
rata aktivitas belajar siswa sebesar 23 dengan kategori cukup, kumudian meningkat pada siklus II dengan skor rata-rata 25 dengan kategori baik dan pada siklus III meningkat lagi menjadi 28 dengan kriteria baik. (2) Penerapan model Learning Cycle 5E pada konsep usaha dan energi dapat meningkatkan hasil belajar kognitif siswa kelas X MIA 3 MAN 2 Kota Bengkulu pada tiap siklusnya. Pada siklus I nilai rata-rata hasil belajar kognitif siswa sebesar 70,25, kemudian meningkat pada siklus II dengan nilai rata-rata 76,41 dan pada siklus III meningkat lagi menjadi 84,61. (3) Penerapan model Learning Cycle 5E pada konsep usaha dan energi dapat meningkatkan keterampilan proses sains siswa kelas X MIA 3 MAN 2 Kota Bengkulu pada tiap siklusnya. Keterampilan proses sains siswa meningkat dari siklus I hingga siklus III terutama keterampilan proses sains pada aspek mengajukan pertanyaan dengan skor rata-rata sebesar 82,04 .

\subsection{Saran}

Berdasarkan penelitian yang telah dilakukan, maka disarankan untuk melakukan perbaikan penelitian dimasa yang akan datang berupa : (1) Disarankan kepada penelitian selanjutnya agar mempertimbangkan alokasi waktu pelaksanaan pembelajaran dan kemampuan awal peserta didik dalam menerapkan model pembelajaran Learning Cycle 5E sehingga dapat terlaksana dengan efektif tanpa kekurangan waktu. (2) Pada pelaksanaan percobaan sebaiknya guru mempertimbangkan jumlah siswa dalam satu kelompok pada saat melakukan praktikum jangan terlalu banyak, agar proses percobaan menjadi lebih baik dan seluruh siswa dapat bekerja dengan

\section{DAFTAR PUSTAKA}

[1] Majid, A. (2013). Strategi pembelajaran. Bandung: Rosdakarya.

[2] Trianto. (2011). Panduan Lengkap Penelitian Tindakan Kelas. Jakarta: Prestasi Pustakarya.

[3] Rustaman, N. (2011). Membangun Literasi Sains Peserta Didik. Bandung: Humaniora.

[4] Wena, M. (2016). Strategi Pembelajaran Inovatif Kontemporer. Jakarta: Bumi Aksara.

[5] Kemendikbud. (2016). Panduan Penilaian Untuk Sekolah Menengah Atas. Jakarta: Kemendikbud.

[6] Tania Bela, Murni. (2017). Penerapan Model Pembelajaran Learning Cycle 5E untuk Meningkatkan Keterampilan Proses Sains Siswa. Jurnal Untirta, 3(1), 68.

[7] Yuliani, Hadma. (2016). Penerapan Model Pembelajaran Learning Cycle Terhadap Motivasi dan Keterampilan Proses Sains Pada Materi Pokok Cahaya. Jurnal EduSains, 4(1), 23. 